\title{
VERBAL BULLYING DALAM MEDIA SOSIAL
}

\author{
NI NYOMAN AYU SUCIARTINI ${ }^{1}$, NI LUH PUTU UNIX SUMARTINI ${ }^{2}$ \\ STMIK STIKOM BALI \\ uci_geg@yahoo.com ${ }^{1}$,pt.unix.sumartini@gmail.com²
}

Pertama Diterima: 4 Agustus 2018

Bukti Akhir Diterima: 7 November 2018

\begin{abstract}
Abstrak
Penelitian ini bertujuan mendeskripsikan, 1) bentuk verbal bullying yang mengemuka di media sosial, 2) penyimpangan prinsip kesantunan berbahasa pada kasus verbal bullying yang mengemuka di media sosial, dan 3) dampak verbal bullying yang mengemuka di media sosial. Dalam mencapai tujuan ini, peneliti menggunakan rancangan penelitian deskriptif-kualitatif. Pengumpulan data dilakukan dengan metode dokumentasi, wawancara, dan kuesioner. Hasil penelitian ini meliputi (1) bentuk perilaku verbal bullying yang mengemuka di media sosial dinyatakan dalam bentuk menyindir, menghina, dan mengancam, (2) bentuk penyimpangan verbal bullying ditinjau dari prinsip kesantunan berbahasa menyalahi maksim kebijaksanaan, kesimpatian, pemufakatan (kecocokan), dan penghargaan, dan (3) dampak verbal bullying yang mengemuka di media sosial dibedakan menjadi 2 yaitu dampak positif, seperti bisa menjadi motivator positif, keinginan kuat untuk berbenah, berani menghadapi tantangan hidup, tetapi dampak negatifnya jauh lebih berat, seperti kehilangan kepercayan diri, disfungsi sosial, penyalahgunaan masa depan, percobaan bunuh diri, dan menjadi pelaku verbal bullying.
\end{abstract}

Kata kunci : verbal bullying, prinsip kesantunan berbahasa

\begin{abstract}
This study aimedat describing, 1) form of verbal bullying which emerges in social media, 2) deviation principle of linguistic politeness in verbal bullying cases which arise in social media, and 3) the impact of verbal bullying which emerges in social media. In achieving this goal, researchers used a descriptive-qualitative research design. Subjectof this study is a user of social media accounts in facebook, path, bbm, twitter, yahoo, and so on. In general, the object of this study is verbal bullying in social media viewed from the perspective politeness principle. Data collections arecolected through documentation method, interviews, and the questioner. The data obtained were analyzed by descriptive qualitative includes three phases, namely, (1) data reduction, (2) the presentation of the data, and (3) verification and drawing conclusions. These results indicate that: (1) the form of verbal bullying which emerges in social media expressed with the intent to be funny, advise, sarcastic, insulting, threatening, (2) forms of verbal bullying deviation in terms of violating
\end{abstract}


the principle of linguistic politeness maxims of wisdom, sympathy, of agreement (compatibility), and awards, (3) the impact of verbal bullying that arise in social media has positive and negative influences.

Keywords :verbal bullying, principle of politeness

\section{PENDAHULUAN}

Bahasa merupakan alat komunikasi sosial yang digunakan oleh masyarakat dalam melakukan interaksi. Menurut Keraf (1991:1) bahasa adalah alat komunikasi antara anggota masyarakat berupa simbol bunyi yang dihasilkan oleh alat ucap manusia. Penggunaan bahasa tidak hanya dilakukan pada masyarakat secara makro,tetapi juga dalam skala mikro seperti pada media sosial. Bahasa memang memiliki peran sentral dalam perkembangan intelektual, sosial, dan emosional. Di dalam berbicara, pembicara dan lawan bicara sama-sama menyadari bahwa ada kaidah-kaidah yang mengatur tindakannya, penggunaan bahasanya, dan interpretasi-interpretasinya terhadap tindakan dan ucapan lawan bicaranya. Setiap peserta tindak tutur bertanggung jawab terhadap tindakan dan penyimpangan terhadap kaidah kebahasaan di dalam interaksi sosial itu.

Mengingat pentingnya kesantunan dalam bertutur, interaksi yang berlangsung dalam media sosial seyogianya dilandasi oleh norma-norma kesantunan. Di dalam berkomunikasi, norma-norma tersebut tampak dari perilaku verbal ataupun nonverbal. Perilaku verbal dalam fungsi imperatif, misalnya, terlihat pada cara penutur mengungkapkan perintah, keharusan, atau larangan melakukan sesuatu kepada mitra tutur, sedangkan perilaku nonverbal tampak dari gerak-gerik fisik yang menyertainya.

Media sosial adalah tempat umum atau publik yang menjadi tempat tumbuh suburnya kasus verbal bullying terhadap suatu kejadian yang sedang heboh diperbincangkan. Banyak orang merasa dirugikan dengan hadirnya verbal bullying ini. Namun, tidak sedikit juga orang, tempat, atau peristiwa makin dikenal karena adanya verbal bullying ini.

Dari hasil observasi awal yang peneliti lakukan di media sosial, seperti facebook, twitter, instagram, path, bbm, dan lain-lain diketahuibahwa banyak terdapat kalimat (bahasa) yang diujarkan pengguna media sosial di facebook dan bbm yang melangkahi koridor kesantunan. Hal ini banyak ditemukan dalam pembahasan soal pemerintahan, politik, bahkan sampai pada ranah pendidikan. Bahasa-bahasa yang kurang santun ini banyak dilontarkan oleh pengguna media sosial dengan dibubuhi gambar yang dramatis untuk mendukung adanya verbal bullying terhadap suatu peristiwa atau kejadian yang tengah hangat diperbincangkan di media sosial. Terdapat juga penggunaan bahasa yang santun dengan gambar yang menukik yang ditujukan dengan maksud menghina atau meledek seseorang atau kejadian yang tengah menjadi pembicaraan publik.

Bullying berasal dari kata bully, yaitu suatu kata yang mengacu pada pengertian adanya "ancaman" yang dilakukan seseorang terhadap orang lain (yang umumnya lebih lemah atau "rendah" dari pelaku), yang menimbulkan gangguan psikis bagi korbannya (korban disebut bully boy atau bully girl) berupa stress (yang muncul dalam bentuk gangguan fisik atau psikis, atau keduanya; misalnya susah makan, sakit fisik, ketakutan, rendah diri, depresi, cemas, dan lainnya). 
Bullying biasanya dilakukan berkelompok, menekan bagian minoritas yang pola hidupnya berbeda dari yang mayoritas. Verbal bullying (terkadang disebut verbal abuse) adalah saat seseorang menggunakan perkataan untuk mendapatkan kuasa di antara sesamanya.

Verbal bullying menggunakan makian yang tidak habis-habis maupun mengolok-olok korbannya, yang biasanya dinilai dari ketidakmampuan fisiknya, maupun mengatai kebodohan dan kegemarannya, suku, agama, maupun fisiknya secara keseluruhan. Walaupun verbal bullying tidak menyebabkan kerusakan fisik, tapi penggencetan seperti ini dapat memberikan dampak buruk pada sisi psikologis korban.

Istilah Bullying belum banyak dikenal masyarakat, terlebih karena belum ada padanan kata yang tepat dalam bahasa Indonesia.Bullying berasal dari kata bully yang diartikan sebagai bully /'bulie/ kb. (j. -lies) penggertak, orang yang mengganggu orang yang lemah. (bullied) menggertak, mengganggu."

Bullying secara verbal, berupa julukan nama, celaan, fitnah, kritik kejam, penghinaan (baik yang bersifat pribadi maupun rasial), pernyataan-pernyataan bernuansa ajakan seksual atau pelecehan seksual, teror, surat-surat yang mengintimidasi, tuduhan-tuduhan yang tidak benar, kasak-kusuk yang keji dan keliru, gosip dan lain sebagainya. Dari ketiga jenis bullying, bullying dalam bentuk verbal adalah salah satu jenis yang paling mudah dilakukan, kerap menjadi awal dari perilaku bullying yang lainnya serta dapat menjadi langkah pertama menuju pada kekerasan yang lebih jauh.

Banyak penelitian mengenai bullying mengindikasikan, pelaku cenderung ingin mendominasi atau mengontrol orang lain. Salah satunya merujuk pada penelitian yang dilakukan oleh Yayasan Semai Jiwa Amini pada tahun 2008, Kekerasan yang terjadi di sekolah tidak hanya dilakukan oleh guru melainkan juga oleh siswa terhadap siswa lain. Dari data kualitatif Focus Group Disscusion (FGD) siswa SD dan FGD guru diketahui bahwa kekerasan yang dilakukan siswa SD terhadap siswa lain masih lebih banyak bebentuk kekerasan berupa hukuman fisik, terutama pada sesama siswa lakilaki. Namun, bentuk bentuk bullying seperti mengejek (verbal) dan psikologis (mengucilkan teman yang tidak disukai) juga sudah terjadi.

Penelitian ini berusaha mengaji kasus verbalbullying yang banyak terjadi di media sosial seperti facebook, bbm, twitter, instagram, dan lain-lain. Penelitian ini juga beranjak dari rasa khawatir penulis oleh kebiasaan anak-anak sekolah bahkan masyarakat umum yang "melabelkan" bahwa verbalbullying memang sesuatu yang wajar untuk menghadirkan lelucon.

Di saat pemerintah sedang gencar melakukan revolusi mental dan pembenahan pendidikan karakter sejak dini, hal semacam ini yang diangkat dalam penelitian ini dianggap penting untuk dikaji. Oleh karena itu, penelitian dengan judul "VerbalBullying dalam Media Sosial”, menarik dan penting untuk dilakukan mengingat kesantunan itu tidak terlepas dengan masalah menumbuhkan karakter yang sedang dibahas secara hangat dalam wacana pendidikan. Peneliti tertarik untuk meneliti sosial media karena di tempat inilah sebagai sumber data dan tempat tumbuh suburnya kasus-kasus verbalbullying yang banyak mendatangkan kontroversi.

Berdasarkan latar belakang yang telah dipaparkan tersebut, permasalahan yang akan dikaji dalam penelitian ini dapat dirumuskan sebagai berikut.(1) Bagaimanakah bentuk prilaku verbalbullying yang mengemuka dalam media sosial? (2) Bagaimanakah penyimpangan prinsip kesantunan dalam 
verbalbullying yang mengemuka di media sosial? (3) Bagaimanakah dampak verbalbullying yang mengemuka di media sosial terhadap pelaku maupun korban bullying?

Sejalan dengan rumusan masalah tersebut, penelitian ini bertujuan untuk mendeksripsikan bentuk prilaku verbalbullying yang mengemuka dalam media sosial (2) bentuk penyimpangan prinsip kesantunan dalam verbalbullying yang mengemuka di media sosial, dan (3) dampak verbalbullying yang mengemuka di media sosial terhadap pelaku maupun korban bullying.

\section{METODE PENELITIAN}

Rancangan penelitian merupakan sebuah strategi untuk mengatur latar penelitian sehingga peneliti benar-benar memperoleh data yang valid sesuai dengan karakteristik dan tujuan penelitiannya. Senada dengan permasalahan yang diangkat, yaitu berkaitan dengan verbal bullying yang mengemuka di media sosial ditinjau dari perspektif prinsip kesantunan berbahasa, maka metode penelitian yang digunakan yaitu rancangan deksriptif kualitatif. Subjek dalam penelitian ini adalah media sosial, baik di facebook, bbm, twitter, ym, dan lain sebagainya. Objek penelitian ini adalah verbal bullying yang mengemuka di media sosial ditinjau dari perspektif prinsip kesantunan berbahasa.

Metode pengumpulan data yang digunakan dalam penelitian ini adalah metode dokumentasi, metode wawancara, dan kuesioner. Setiap metode memiliki peran dalam pengumpulan data. Tujuan dari dokumentasi ini adalah untuk memperoleh sudut pandang orisinal dari kejadian situai nyata. Dokumen resmi dipandang mampu memberikan gambar mengenai aktivitas, keterlibatan individu pada suatu komunitas tertentu dalam setting sosial. metode dokumentasi ini digunakan untuk menjawab adanya bentuk verbal bullying dan bentuk penyimpangan verbal bullying ditinjau dari prinsip kesantunan berbahasa. Dalam penelitian ini peneliti memilih metode wawancara tidak berstruktur. Dalam wawancara tidak berstruktur memberikan ruang kebebasan bagi pewawancara untuk menggali informasi yang diperlukan. Akan tetapi, dalam hal ini peneliti menggunakan satu pertanyaan memancing untuk mengungkapkan hal-hal yang lebih luas. Selain itu, dalam penelitian ini juga digunakan metode kuesioner yang digunakan pengumpulan data dengan jalan mengajukan pertanyaan atau pernyataan tertulis kepada sejumlah individu sebagai bahan pertimbangan dan pengembangan.

\section{HASIL DAN PEMBAHASAN}

\section{Bentuk-Bentuk Perilaku Verbal Bullying yang Mengemuka di Media Sosial}

Kalimat-kalimat yang mengemuka di media sosial seperti facebook, blackberry messager (bbm), instagram, dan twitter mengandung beragam maksud seperti hendak, menyindir, menghina, bahkan mengancam. Disadari atau tidak oleh pengguna akum media sosial, bahwa kalimat-kalimat yang terpampang di media sosial tersebut dapat menimbulkan efek lain atau mengundang komentarkomentar yang tidak terduga, salah satunya dapat digolongkan ke dalam bentuk perilaku verbal bullying. Berikut ini beberapa data terkait bentuk perilaku verbal bullying dengan maksud-maksud tertentu yang menjadi sorotan dunia maya bahkan menggegerkan publik baik dalam ranah pendidikan, politik, maupun pemerintahan. 


\subsection{Bentuk Perilaku Verbal Bullying yang Menyindir}

Verbal bullying juga dapat dinyatakan dengan maksud menyindir. Berikut ini dipaparkan beberapa data terkait bentuk verbal bullying yang bermaksud menyindir baik dalam posting-an maupun komentar netizen di media sosial.

1). Posting-an akun grup meme terkait fenomena Kota Bekasi

(konteks: Kota Bekasi menjadi bahan perbincangan di dunia maya. Banyak netizen membully Kota Bekasi karena dinilai sebagai kota yang panas, infrastruktur yang rusak parah, yang menyebabkan pengunjung merasa tidak nyaman melintas atau berkunjung ke Kota Bekasi)
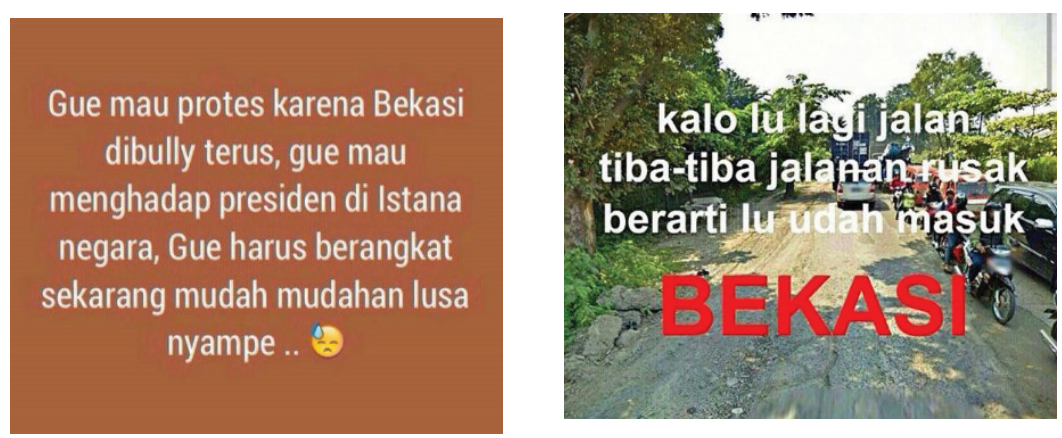

(sumber : twitter dan instagram akun grup meme)

Posting-an akun grup meme kian marak beredar yang ditandai dengan gambar-gambar dan kalimat-kalimat yang dimaksudkan untuk menyindir Kota Bekasi. Bekasi sontak disoroti oleh netizen sebagai kota yang tidak nyaman di tengah gemerlapnya perkotaan. Netizen yang mengunjungi Bekasi membuat komik meme dengan posting-an kalimat-kalimat menyindir keadaan wilayah Bekasi yang sangat panas, jalanan rusak dan berbatu, dan segala kondisi yang dirasakan tidak nyaman oleh pengunjung. "Kalau lu jalan, tiba-tiba jalan rusak, berarti lu udah masuk Bekas dan Kenapa ya Bekasi dibully terus? Besok mau lapor ah. Mudah-mudahn lusa udah sampai, Matahari Bekasi ada dua ya?", kalimat-kalimat tersebut dapat digolongkan ke dalam verbal bullying dengan menyudutkan Bekasi sebagai kota tidak nyaman bahkan sebuah daerah yang terpisah dari Indonesia. Bully terhadap Kota Bekasi juga merambah ke daerah lain di Indonesia. Di masyarakat juga fenomena bully Bekasi ini mencuat. Jika keadaan panas, gerah, dan tidak nyaman, sontak seseorang menyebutkan anak Bekasi ya?

Di tengah banyaknya bulying menyindir keadaan Kota Bekasi yang tersebar di dunia maya, warga Bekasi juga mengajukan beberapa pembelaan bahwa Bekasi tidak lebih buruk dari kotakota lain yang infrastrukturnya tidak tersedia dengan maksimal.

\subsection{Bentuk Perilaku Verbal Bullying yang Menghina}

Berikut ini dipaparkan data mengenai verbal bullying dalam media sosial yang bermaksud menghina.

1). Status di twitter dan path akun Florence

Jogja miskin, tolol, dan tak berbudaya. Teman-teman Jakarta-Bandung jangan mau tinggal Jogja. 
Orang Jogja B******. Kakak mau beli Pertamax 95 mentang-mentang pake motor harus antri di jalur mobil terus enggak dilayani. Malah disuruh antri di jalur motor yang stuck panjangnya gak ketulungan. Diskriminasi. Emangnya aku gak bisa bayar apa. Huh. KZL.

Komentar

“@florencje_Status S2, cara berpikir \& ngomongnya kok KAMPUNGAN. Keluar aja dari Yogya," demikian komentardari akun@mercurianearth.

"Banyak yg mencintai jogja kan ya, makanya satu org yg ngatain jogja, semua pada maju. Oo dasar florence, kuliah si S2 UGM eh tetapi mulutnya,”tulisUlvah, @ulpainaya.

Komentarlainnyadikirimkanakun@senorita_eve“kasihandgncewe@florencje_niy,ngakuny S2 tetapi cara bicarany enggak ada cerminan intelektualnya.

(konteks: status Florence muncul di media sosial akibat rasa tidak puas sang pemilik akun terhadap pelayan SPBU di Yogyakarta. Si pemilik akun merasa kesal karena harus mengatri panjang untuk membeli premium. Status itu dibuat dengan maksud menyinggung pegawai SPBU yang tidak melayani dengan prima)

Tulisan Florence Jogja miskin, tolol, dan tak berbudaya membuat Florence dibully begitu hebohnya di dunia maya. Kalimat yang di-posting-annya di akun path tersebut secara langsung menghina Kota Yogyakarta dan masyarakat Yogyakarta. Penyebutan Kota Yogyakarta secara jelas tertulis dalam posting-an Florence dan komentar pedasnya terhadap Kota Yogyakarta. Kalimat penghinaan Florence terhadap Kota Yogyakarta beserta isinya ini ditanggapi serius oleh netizen. Kicauan Florence di media sosial yang dinilai menghina warga Yogyakarta berbuntut panjang. Setelah berbagai kecaman muncul di dunia maya, Florence sang pemilik akun juga harus berhadapan dengan pihak berwajib. Kalimat yang dilontarkannya di status yang bernada menghina pelayanan SPBU Kota Yogyakarta membuatnya di-bully di media sosial. Perempuan yang disebut-sebut kuliah S-2 FH UGM ini resmi dilaporkan ke Polda DIY. Mem-bullyKota Yogyakarta dengan segala kekurangannya menurut Florence, berbuntut balik ia yang menjadi korban bullying yang menyudutkan Florence sebagai seorang yang tak berpendidikan. Diberitakan sebelumnya, akun media sosial kembali diramaikan dengan posting-an kontroversial dari pemilik akun path bernama Florence. Wajar saja, ia menuliskan keluh kesahnya saat mengantre BBM yang ternyata dinilai sangat menghina warga Yogyakarta. Hasil captureposting-an di path tersebut kemudian diunggah ke jejaring twitter. Sontak saja, hal ini kemudian memancing protes keras dari para pengguna twitter lainnya bahkan komentarkomentar negatif pun melekat pada diri Florence. Florence mendapat nama baru atau label baru sebagai sampah Yogyakarta, sampah pendidikan, otak anjing, perempuan paling ngehe, yang datang kepada dirinya yang dilontarkan netizen dalam komentar-komentar terhadap status Florence. Kalimat-kalimat inilah yang digolongkan ke dalam verbal bullying dengan korban Florence dan juga sekaligus Florence sebagai pembully. Kalimat bernada negatif yang dilontarkan 
Florence dengan membully Kota Yogyakarta yang akhirnya mengantarkannya dihujat secara massal oleh netizen dan dianggap sebagai korban bullying akibat kalimat-kalimatnya sendiri. Kasus verbal bullying ini sempat membuat Florence tetap mempertahankan pendapatnya lewat posting-an-posting-an yang mendukung bahwa dirinya tidak bersalah. Namun, respons dari netizen tidak berubah dan kembali memberi julukan-julukan negatif untuk Florence.

\subsection{Bentuk Perilaku Verbal Bullying yang Mengancam}

Berikut ini dipaparkan beberapa data mengenai adanya verbal bullying dengan maksud mengancam yang diposting netizen di media sosial.

1).Komentar netizen terkait posting-an status Ibnu yang melecehkan Nyepi di Bali

"Mai alih ne madan Ibnu, bang Cetik crongcopolo" (Cari Ibnu, kasi ilmu hitam)

"Kalau ketemu di jalan, saya ludahi kamu, Ibnu!"

"Makanya jangan ke Bali, di Bali amah leak cai!" (Makanya jangan ke Bali, di Bali dimakan leak kamu!)

(konteks: beberapa komentar tersebut dinyatakan netizen dalam grup publik anti-Ibnu yang dibuat oleh sekelompok orang yang mengecam Ibnu sebab telah melecehkan budaya dan hari suci Nyepi di Bali)

Netizen, khususnya yang ada di Bali sontak merespons kalimat posting-an Ibnu yang melecehkan adat Nyepi di Bali. Komentar tersebut berisi makian balik, hinaan juga beberapa ancaman terhadap Ibnu terkait ulahnya yang dianggap sangat tidak santun dengan memposting kalimat Nyepi sepi sehari kaya tai. Beberapa kelompok juga membuat grup anti Ibnu yang membully remaja ini. Ketika persoalan agama, ras, adat istiadat, dan hal-hal yang sangat sensitif lainnya dihina atau dilecehkan, respons yang datang pun akan menghebohkan, seperti kasus yang dialami Ibnu hingga dilaporkan ke pihak yang berwajib. Netizen memberi label negatif kepada Ibnu sebagai manusia anjing, manusia gak punya otak, mulut sampah, dan lain sebagainya. Komentar-komentar yang berisi pencekalan terhadap Ibnu untuk datang ke Bali juga datang dari netizen. Ibnu mendapat ancaman secara psikologis maupun sosial tidak hanya dari masyarakat Bali yang dilecehkannya, melainkan masyarakat luar Bali juga turut memberikan label negatif terkait posting-an Ibnu yang dianggap tidak beretika dan posting-an sampah.

“Nyepi sepi sehari kaya tai..”, Kalimat ini secara tidak langsung dianggap mengina Bali, Hindu, dan penduduk yang tengah menjalankan hari suci Nyepi. Ribuan komentar buruk yang balik membully Ibnu berdatangan. Usir gen jeleme care kene (usir saja orang ini), Hanya anak pelacur yg menghina bali. Manusia sampah”, "wah....ibnu ibnu......setelah saya liat kamu ternyata kamu setengah cowok setengah cewe...he he he banci kamu ibnu....pasti sering nongkrong.......di renon ...(trex bencong)", serta komentar-komentar yang menyebut anti Ibnu.

Tidak menunggu waktu lama, reaksipun ditunjukkan dengan mencuatnya angka 6.000 
pengguna Facebook yang tergabung dalam grup anti Ibnu. Belum lagi beberapa grup lain yang senada. Entah karena merasa bersalah ataukah khawatir bahwa kebodohannya akan berbuntut panjang, pria bernama Ibnu Rachal Farhansyah ini kemudian membuat satu grup tandingan "maafkan Ibnu Rachal Farhansyah" yang hanya mendapatkan 150 anggota. Masyarakat Indonesia, khususnya Bali menjadi sangat kecewa dengan posting-an ini. Ibnu sendiri mengalami tekanan yang luar biasa secara emosional maupun psikologis terhadap lingkungan masyarakat sekitarnya. Ibnu akhirnya menutup akun facebook dan kasus ini ditangani pihak kepolisian Bali.

\section{Bentuk Penyimpangan Prinsip Kesantunan Berbahasa pada Kasus Verbal Bullying yang Mengemuka di Media Sosial}

Kalimat-kalimat yang mengemuka di media sosial yang diujarkan para netizen dengan maksud tertentu terkadang tidak berterima di hati pemilik akun dunia maya yang lainnya, sehingga menyebabkan tuturan dalam status maupun komentar-komentar yang mengikutinya dianggap sebagai tuturan yang tidak santun. Hal ini disebabkan oleh adanya penyimpangan-penyimpangan terhadap maksim-maksim kesantunan dalam bertutur. Disadari atau tidak oleh para netizen di dunia maya ini, penyimpangan terhadap maksim-maksim kesantunan tersebut menyebabkan tuturan dalam status dan komentar-komentar yang mengikutinya menjadi tidak santun. Ketidaksantunan tuturan itu muncul disebabkan oleh berbagai hal yang melatarinya, seperti konteks sosial saaat status atau komentar dikemukakan, emosi netizen, topik pembicaraan, dan hubungan sosial. Berikut ini dipaparkan bentuk tuturan dalam kalimat-kalimat yang mengemuka di media sosial seperti facebook, twitter, path, instagram, dan bbm yang menyimpang dari prinsip maksim kebijaksanaan, kesimpatian, penerimaan, pemufakatan (kecocokan), dan kesederhanaan, dan penghargaan.

\subsection{Bentuk Penyimpangan Maksim Kebijaksanaan pada Kasus Verbal Bullying yang Mengemuka di Media Sosial}

1).Status Akun Reksa di Facebook

"Siswa terlambat dihukum, kalau guru datang lambat tidak masalah. Dasar pak GEPENG"

Komentar:

Pak Gepeng juga buat Gepeng ya? Hahahaha” tulis akun Re

"emosi aku! Macam robot saja dibikinnya kita, usah takut kau Wi ....dibelakang kau ada 500 siswa yang dukung Wi”

Awas ketahuan tuh! Tembok ajah punya telinga!

(konteks: pemilik akun Re menuliskan status yang menyindir gurunya di facebook. Status ini memicu komentar-komentar mendukung juga memojokkan sang pembuat status. Akibat negatif tulisan ini tidak hanya dialami di dunia maya dengan munculnya komentar negatif, melainkan di dunia nyata mengakibatkan pemilik akun Re dikeluarkan dari sekolahnya bersama 3 orang siswa yang memberikan komentar pendukung status Re) 
Berawal dari kekesalan seorang siswa akibat perlakuan yang dianggap tidak adil antara guru dan siswa membuat Re menuliskan status tersebut. Re bermaksud menumpahkan kekesalan akibat guru yang sering datang terlambat tidak mendapat hukuman yang sama dengan siswa yang datang terlambat. Bahkan keterlambatan guru ini sering ditoleransi sebagai sebuah kewajaran, sedangkan siswa harus mendapat hukuman sebagai efek jera terhadap keterlambatannya. Status yang mengemuka di media sosial facebook sontak menghadirkan komentar pro dan kontra terhadap kalimat Re. Banyak yang berkomentar bahwa Re tidak pantas menuntut guru dan tidak layak sebab Re dihukum karena masalah yang selalu dilakukannya berulang di sekolah. Komentar pro terhadap status Re ditujukan untuk menegakkan keadilan kepada seluruh warga sekolah, baik guru, kepala sekolah, pegawai, maupun siswa itu sendiri. Status ini tidak hanya menjadi kisruh dan perbincangan dunia maya yang banyak juga memojokkan Re sebagai bentuk penghinaan terhadap guru dan sekolahnya. Di dunia nyata pun status $\mathrm{Re}$ ini mengakibatkan dikelurakannya Re bersama 3 orang siswa lainnya yang turut mendukung status Re yang mengemuka di media sosial. Re bersama teman-temannya mendapat kecaman dan kalimat-kalimat negatif terkait etika yang dianggap tidak patut. Status beserta komentarkomentar dalam facebook pemilik akun Re ini dapat digolongkan ke dalam salah satu bentuk verbal bullying karena membuat Re dan 3 teman lainnya merasakan ketidaknyamanan dalam menuntut ilmu di sekolah. Mereka kerap mendapat cibiran yang datang dari pihak guru maupun siswa. Kepala sekolah serta guru juga ikut mengalami verbal bullying karena dianggap sebagai sosok yang tidak tahan terhadap kritikan dan cenderung tidak bijaksana dalam menghadapi suatu permasalahan.

Kalimat yang mengemuka di facebok tersebut dikategorikan menyimpang dari maksim kebijkasanaan yang tidak memaksimalkan keuntungan mitra tutur. Gagasan maksim kebijaksanaan dalam prinsip kesantunan adalah bahwa peserta tutur hendaknya berpegang pada prinsip untuk mengurangi keuntungan diri sendiri dan memaksimalkan keuntungan pihak lain dalam kegiatan bertutur (Rahardi, 2008:60). Penutur yang tidak mematuhi dan melaksanakan maksim kebijaksanaan ini dapat dikatakan sebagai orang yang kurang atau tidak santun. Dari hasil penelitian diketahui bahwa dalam percakapan yang berlangsung di facebook tersebut menyimpang dari maksim kebijaksanan. Tindak tutur tersebut cenderung menghadirkan perasaan kecewa, sakit hati, minder, dan sebagainya.

Sesuai dengan prinsip maksim kebijaksanaan yang menekan sekecil mungkin kerugian di pihak orang lain tuturan dalam percakapan tersebut dapat digolongkan sebagai tuturan yang menyimpang dari maksim kebijaksanaan. Dalam situasi dan kondisi semacam itu, siswa seharusnya lebih hati-hati ketika menuliskan status terlebih dalam mengomentari perilaku guru serta kebijakan yang menyangkut pautkan pihak sekolah. Pihak sekolah pun dalam menanggapi status siswa semacam ini harusnya lebih berhati-hati dan tidak mengedepankan label negatif dari pemilik akun Re tersebut. Akibat tuturan ini, suasana pembelajaran dan sekolah berubah menegangkan dan penuh tekanan. 


\subsection{Bentuk Penyimpangan Maksim Kemufakatan pada Kasus Verbal Bullying yang Mengemuka di Media Sosial}

1).Status akun Ria di Facebook terkait rasa kesalnya pada kebijakan pendidikan, terutama UN.

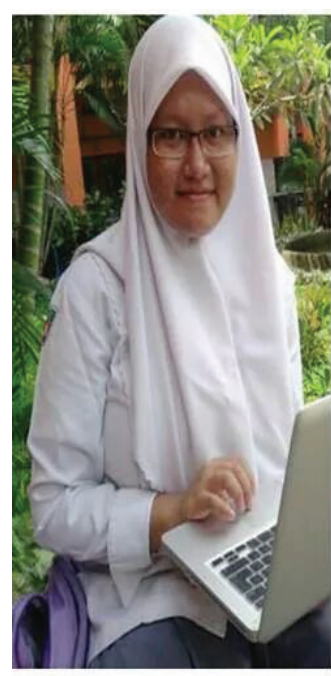

Saya tantang Bapak untuk duduk dan mengerjakan soal Matematika yang

kami dapat di UNAS kemarin selama dua jam tanpa melihat buku maupun

internet. Jika Bapak bisa menjawab

benar lima puluh persen saja, Bapak

saya akui pantas menjadi Menteri. Kalau

Bapak berdalih 'ah, ini bukan bidang

saya', lantas Bapak anggap kami ini apa?

Apa Bapak kira kami semua ini anak

OSN? Apa Bapak kira kami semua pintar

di Matematika, Fisika, Biologi, Kimia,

Bahasa Indonesia, dan Bahasa Inggris

sekaligus? Teganya Bapak menyuruh

kami untuk lulus di semua bidang itu?

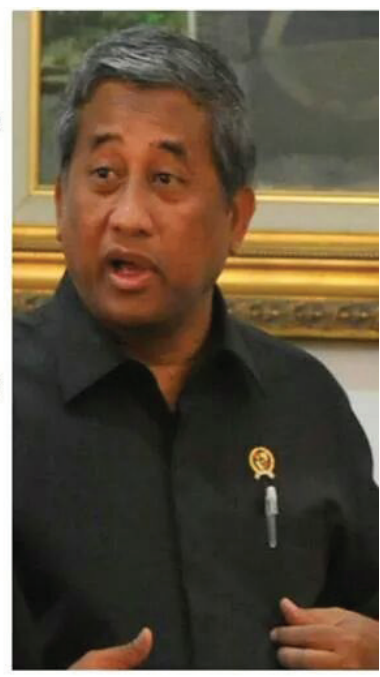

(sumber : Status akun Ria di Facebook)

Komentar:

1. SD kami UN pertama kali, SMP kami UN dgn 5 pkt, SMA kami UN dgn 20 pkt standar internasional. Kita bukan kelinci percobaan pak!!@Mohammad_Nuh_tulis pemilikakun Twitter@dewaagung.

2. Bukan ngeluh pak, kita usaha sih tetap usaha tetapi bapak harusnya mikir juga gak semua anakpunya otak olimpiade matematika@Mohammad_Nuh_tulisakunTwitter@uyasuur.

3. Trims pak sll menjadikn tahun saya menjadi kelinci percobaan. Soal UNnya sangat melenceng dariskl\&tryout2:)@Mohammad_Nuh_@Kemendikbud_RI, tutur Natasya Putri Dewi lewat Twitter@tasyawidik.

4.Selamatpak@Mohammad_Nuh_UN udah kelar, Cuma berharap jangan sampe keulang lagi, system pendidikan masih tradisional eeh UNnya internasional, ujar Desti Laili lewat akunTwitter@relatsani_yoo.

(konteks: terkait ujian nasional yang digelar tahun 2014 banyak siswa yang mengeluhkan bahkan mem-bully menteri pendidikan Mohammmad Nuh terkait pelaksanaan ujian nasional yang tidak maksimal dan tidak sesuai dengan standar pendidikan yang berlaku di sekolah). 
Pelaksanaan ujian nasional tahun 2014 mendatangkan banyak polemik yang tidak berkesudahan. Polemik inilah yang membuat beberapa siswa, guru, maupun masyarakat lantas menuliskan keluh kesahnya terkait ujian nasional dengan sistem dan evaluasinya yang dianggap tidak sesuai. Status-status dan komentar bernada mem-bully menteri pendidikan saat itu, Mohammad Nuh mulai membanjiri media massa. Seperti status Ria dengan jutaan komentar negatif terkait ujian nasional yang telah peneliti tuliskan tersebut mendapat respons dari berbagai pihak yang menyatakan setuju bahwa menteri pendidikan menganggap siswa atau sekolah sebagai kelinci percobaan. Hingga muncul sebuah kalimat perbandingan yang menantang sang menteri pendidikan untuk menghadapi ujian serupa siswa. Apabila sang menteri berhasil, maka sejuta netizen akan menganggap sang menteri hebat. Kebijakan terkait ujian nasional terus mendapat sindiran bahkan cercaan dan berujung pada bully bahwa menteri pendidikan dan jajarannya dianggap tidak berhasil menyelenggarakan evaluasi pendidikan yang baik untuk Indonesia. Munculnya kalimat-kalimat baik dalam status maupun komentar pengguna media sosial terkait pelaksanaan ujian nasional yang bernada negatif bahkan membully menteri pendidikan membuat Mohammad Nuh angkat bicara lewat akun twitternya. Melalui akun Twitternya juga, dirinya mencoba menjawab berbagai keluhan para siswa melalui tag \#UN2014

1. Adik2 yg ikut \#UN2014, terima kasih atas respons tentang tingkat kesulitan soal.

2. Jika ada soal yang dirasa sulit, hal itu wajar karena selalu ada soal baru dalam setiap ujian. Ini salah 1 esensi ujian. \#UN2014

3. Di tahun-tahun sebelumnya juga selalu ada siswa/I yg merasa kesulitan karena mendapat soal yg baru \#UN2014

4. Soal baru adalah soal yg blm pernah adik-adik temui ditemukan dalam soal-soal latihan. \#UN2014

5. Kami yakin soal baru tersebut dpt dikerjakan dg benar u/ adik2 yg sudah belajar tekun, meski dirasa sulit \#UN2014

Komentar:

1.Ciyus?? Pak menteri yang terpintar mulai sangar_tulisakun@Diadra

2.Gorila coklat yang manis....baru dimakan pahit banget_tulisakun@Badrok

Pembelaan Menteri pendidikan ini tetap mendapat komentar negatif dari netizen. Ketidakcocokan pemikiran jajaran pemerintahan, terutama Menteri Pendidikan dengan siswa dan praktisi pendidikan di sekolah, membuat komentar dan status perihal ujian nasional terus bermunculan. Hingga penyebutan secara tidak langsung Menteri Pendidikan sebagai sosok gorila berwarna coklat yang semakin membuat netizen melakukan verbal bullying secara berkelanjutan. Kalimat-kalimat bernada negatif yang ditujukan para netizen yang mengandung verbal bullying ini dianalisis dari segi prinsip kesantunan berbahasa sebagai sebuah kalimat yang melanggar maksim kemufakatan atau maksim kecocokan. Maksim kecocokan atau kemufakatan menggariskan setiap penutur dan lawan tutur untuk memaksimalkan kecocokan 
di antara mereka, dan meminimalkan ketidakcocokan di antara mereka. Sesuai dengan prinsip maksim kemufakatan, netizen dapat menyatakan ketidaksetujuan terhadap kebijakan pendidikan, khususnya kebijakan ujian nasional dengan kalimat saran yang membangun. Netizen semestinya tidak mengungkapakan kalimat bernada verbal bullying, terlebih lagi memberikan label negatif kepada menteri pendidikan terkait kebijakan ujian.

Media sosial adalah tempat umum yang seharusnya juga berlaku kesopanan dalam bertutur yang diungkapkan dalam status maupun komentar-komentar terhadap sesuatu dan tidak menyinggung pihak-pihak apalagi memberi dampak negatif kepada seseorang. Terdapatnya penyimpangan maksim kemufakatan atau kecocokan dalam kalimat-kalimat netizen digolongkan dalam verbal bullying. Penyimpangan maksim kemufakatan atau kecocokan sesuai dengan prinsip kesantunan berbahasa mengakibatkan suasana berbalas status ataupun komentar di dunia sosial semakin keruh. Semuanya mengggap apa yang dilakukan sudah semestinya atau sudah dalam koridor yang benar, baik di pihak sekolah, siswa, maupun pemerintah pendidikan itu sendiri. Ketimpangan pendapat pun menjadi hal yang tidak bisa dihindari mencuat di media sosial.

\subsection{Bentuk Penyimpangan Maksim Kesimpatian pada Kasus Verbal Bullying yang Mengemuka di Media Sosial}

Kesimpatian terhadap sesuatu yang tengah terjadi dikehidupan nyata banyak yang diabaikan oleh netizen di dunia maya, salah satunya di media sosial. Beberapa netizen justru memperolok sebuah kejadian menjadi hiburan atau humor dengan menghadirkan gambar animasi dan kata-kata yang lucu terhadap peristiwa atau tokoh yang tengah diperbincangkan. Kasus semacam ini dapat digolonggkan dalam salah satu contoh kasus verbal bullying yang melangkahi koridor prinsip maksim kesimpatian dalam kesantunan berbahasa yang dirumuskan oleh Leech (1993).

1). Status R. Fadilah Muchtar Natanegara di Path

Semoga pesawat murahan banyak jatuh dan banyak hilang di angkasa dan tersisa 1 perusahaan yang sangat gue dan keluarga gue percaya yaitu Garuda Indonesia kata Fadilah Muchtar dalam akun Path-nya. Program Path mendeteksi Fadilah berada di Jakarta Selatan saat menulis kalimat tersebut sebagai status Path-nya.

Komentar:

"Ya kan semua orang belum tentu berduit buat naik garuda toh.. say," tulis Redy dalam komentarnya

Semiskin-miskin dan enggak punya duitnya gue, gue enggak pernah naik yang murahan itu. Karena gue tau nyawa gue yang gue pertaruhkan dalam bepergian lewat udara, jadi lebih baik gue bayar mahal tetapi nyawa terjamin," balas Fadilah

Para pengguna Path mengunggah ulang foto status Fadilah dan mengomentari dengan berbagai kalimat pedas. 
"Waktu antre pembagian otak, dia masih main lumpur limbah kotoran. Makanya kayak gini \#jengkelabis ripet Shal," kata salah seorang pengguna Path, Angela.

"Klo papasan, kita shalat jenazahin bareng yuk mbak. Saya rela deh belajar shalat jenazah demi masukin dia ke liang kubur," Shal, teman Angela, ikut berkomentar.

"Kok ada ya orang kayak gini? Miris banget bacanya. Mudah-mudahan temennya bisa ngajarin ya," balas Nesa

(konteks: Seorang lelaki pengguna media sosial Path, R. Fadilah Muchtar Natanegara, mencela insiden hilangnya pesawat Air Asia QZ8501 yang hilang di atas perairan Tanjung Pandan, Bangka Belitung. Fadilah mendoakan agar semakin banyak pesawat berbiaya murah yang hilang dan jatuh. Status Fadila ini mendapat kecaman dari netizen dan dibully sebagai orang yang tidak punya empati).

Manusia yang tidak punya otak, manusia tak berempati, manusia planet lain, dan sebutansebutan negatif lainnya datang kepada seorang remaja bernama Fadilla sesaat sesudah status yang dibuatnya menghebohkan dunia maya. Status Fadilla yang berisikan doa agar penumpang Air Asia tidak ada yang selamat dan banyak pesawat dengan harga murah agar jatuh dikecam netizen di dunia maya. Kemunculan statusnya ini membuat ribuan komentar negatif datang kepadanya. Fadilla dibully secara verbal sebagai manusia yang tidak mempunyai etika dan otak. Kutipan statusnya di akun path "semoga pesawat murahan banyak jatuh dan banyak hilang di angkasa dan tersisa 1 perusahaan yang sangat gue dan keluarga gue percaya yaitu Garuda Indonesia"dapat digolongkan kasus bullying secara verbal terhadap korban jatuhnya pesawat Air Asia. Kalimat bernada bully ini juga menyalahi prinsip kesantunan berbahasa, khususnya maksim kesimpatian. Sesuai prinsipnya, maksim kesimpatian ini mengharuskan setiap peserta pertuturan untuk memaksimalkan rasa simpati, dan meminimalkan rasa antipati kepada lawan tuturnya. Bila lawan tutur memperoleh keberuntungan atau kebahagiaan, penutur wajib memberikan ucapan selamat. Jika lawan tutur mendapatkan musibah, penutur sudah sepantasnya menyampaikan rasa duka atau bela sungkawa sebagai tanda kesimpatian. Status Fadila tidak menunjukkan kesimpatiannya, bahkan cenderung menghina dan melecehkan para korban dan kejadian naas yang dialami korban jatuhnya pesawat AirAsia di Selat Karimata tersebut. Komentar-komentar netizen juga bernada negatif dengan membully Fadila sebagai manusia yang tidak mempunyai otak, manusia tidak berempati, bahkan mahkluk asing yang datang dari planet lain. Respons netizen ini dianggap wajar karena kalimat yang diungkapkan Fadila lewat statusnya benar-benar mencerminkan sosok manusia yang tidak memiliki sifat kemanusian. 


\section{Dampak Verbal Bullying dalam Media Sosial}

\subsection{Dampak Positif Verbal Bullying dalam Media Sosial}

Dalam sejumlah refrensi yang peneliti gunakan, belum ada yang memuat bahwa verbal bullying yang terjadi pada individu dapat menyebabkan dampak positif. Namun, dalam penelitian ini, peneliti menemukan temuan bahwa dalam konteks tertentu untuk beberapa individu maupun komunitas tertentu mampu menunjukkan bahwa verbal bullying yang pernah dilontarkan kepadanya membawa dampak positif yang terjadi secara tidak langsung. Verbal bullying seolah menjadi trend di dunia maya saat ini. Para netizen yang menjadi korban bullying ini tidak selamanya merasa tertekan, kehilangan kepercayaan diri, malah sebaliknya, mereka sejenak menjadi tokoh yang dicari para netizen, artis yang terkenal dadakan, bahkan kalimatkalimat yang diungkapkannya di status maupun komentar tidak menutup kemungkinan menjadi trend dan ditiru khalayak media sosial. Netizen yang dibully ini terkadang menikmati verbal bullying tersebut sebagai keuntungan, sebab dibuat bahan humor atau bahan tertawaan dengan menghadirkan bully dalam bentuk yang lainnya yang notabenennya semakin membuat netizen tersebut terkenal dan menjadi perbincangan dunia maya. Berikut ini beberapa dampak positif yang dirasakan korban verbal bullying yang mengemuka di media sosial.

Seseorang yang menjadi korban verbal bullying akan termotivasi untuk berani membela dirinya dihadapan orang lain, menunjukkan kelebihannya di hadapan umum setelah merasa direndahkan atau diberikan label negatif. Verbal bullying menjadi pemacu positif hanya untuk mereka yang memiliki mental yang kuat. Seseorang yang memiliki mental kuat akan berusaha menunjukkan kelebihan atas pengucilan atau perendahan dirinya. Bagi korban verbal bullying yang tidak memiliki mental kuat dalam menerima kritikan maupun komentar negatif terhadap dirinya, mungkin mereka akan melakukan tindakan-tindakan negatif. Motivator positif bagi yang memiliki mental yang kuat terhadap praktik verbal bullying dapat dilihat dari beberapa contoh berikut ini.

Kemunculan gaya bahasa Vicky Praseto yang diunggah di Youtube dan menyebar ke media sosial seperti facebook, instagram, bbm, bahkan twitter. Vicky Prasetyo merupakan seorang biasa yang tiba-tiba muncul dengan gaya bahasanya yang dianggap bahasa dunia lain oleh para netizen mendapat sambutan bully yang bertubi. Berikut ini beberapa kalimat Vicky yang dibully di media sosial. Kalimat ini dikutip dari perbincangan Vicky di infotaiment.

"Jika sebuah hungan tidak di dasari oleh adanya perhatian dan kesetiaan maka bersiap - siaplah untuk menghadapi kontroversi hati yang sangat sulit untuk di pecahkan.”

"Di dalam sebuah perjalanan kehidupan yang meliputi cinta, karir dan berosialisasi tidak akan tercipta sebuah konspirasi kemakmuran jika di dalamnya tidak terdapat sebuah persamaan dalam sebuah tujuan."

"Untuk menjungjung tinggi nilai harmonisisasi tidaklah mudah karena harmonisisasi hanya akan terwujud apabila kita tidak meremehkan segala persoalan dari hal yang terkecil sekalapin hingga hal yang terbesar yang kita temui dalam kehidupan."

"Tidak ada unsur mengudeta dalam sebuah urusan cinta karena cinta adalah ketulusan untuk memberi dan menerima melalui perasaan yang sempurna." 
"Cinta itu buta karena cinta tidak pernah memandang statusisasi sesorang melalui tahta, rupa maupun harta."

Kalimat-kalimat ini mendapat cibiran dari para netizen dengan komentar-komentar yang dilayangkan untuk membully Vicky Prasetyo. Ada netizen yang berkomentar bahwa Vicky sebagai sosok manuasia baru dengan gaya bahasa betonisasi, ada pula netizen yang menyebut Vicky dengan sebutan sok intelek tetapi kampungan dan tidak paham kalimatnya sendiri. Terlepas dari semua komentar negatif yang membully Vicky, ia sendiri semakin dikenal dunia dengan gaya bahasanya yang khas bahkan menjadi trend berbahasa di kalangan masyarakat umum beberapa pekan.

Kata 'Apresiasi,' 'Kontroversi,' 'Konspirasi,' 'Kemakmuran,' 'Harmonisasi,' 'Ego,' 'Kepentingan,' 'Mengkudeta,' 'Confident,' 'Mensiasati,' 'Kecerdasan,' 'Labil,' dan 'Ekonomi' , 'statunisasi' yang penempatannya tidak sesuai dikenal dengan gaya bahasa khas milik Vicky. Hampir semuanya adalah kata-kata serapan dari bahasa Inggris yang biasa dipergunakan untuk kepentingan penulisan analisis berita-berita politik. Akan tetetapi, persoalan kemudian muncul ketika Vicky menggunakan semua kata milik para 'analis politik' itu dalam konteks yang sangat personal, sebagai sebuah pernyataan publik. Lebih-lebih, bahasa tubuhnya saat berucap kalimatkalimat di muka mengesankan adanya kepercayaan diri yang sungguh besar.

Hal inilah yang menyebabkan netizen merasa geli dan mem-bully Vicky Prasetyo. Namun, siapa sangka dengan datangnya bully terhadap Vicky membuatnya semakin terkenal, hingga akhirnya Vicky berhasil masuk ke salah satu televisi swasta dan diundang sebagai bintang tamu dan kerap muncul di layar kaca membawakan beberapa program tertentu. Vicky membiarkan para netizen untuk mem-bully-nya secara terus menerus sebab dia tahu bahwa hal itu akan mendatangkan keuntungan baginya. Vicky hanya menanggapi dengan senyuman meski labellabel negatif kerap datang pada dirinya.

Kepercayaan diri Vicky yang terlampau tinggi ini bisa menahan Vicky dari serangan verbal bullying yang cenderung membuat korbannya merasa tertekan, terhindar, bahkan tidak jarang yang menutup akun sosialnya demi menghindari efek verbal bullying tersebut. Namun, rasa tidak nyaman, kurangnya kepercayaan diri, merasa dikecam oleh komunitas sosial tidak nampak dalam diri Vicky. Ia mengaku bahwa rasa percaya dirinya tampil di layar kaca semakin tinggi karena dirinya dikenal dengan bahasa yang khas. Hal ini mungkin akan berlaku terbalik bagi mereka, seseorang yang tidak memiliki kemantangan sosial atau kepercayaan diri yang tinggi. Jika mendapat kalimat-kalimat bernada verbal bullying, cenderung seseorang akan merasa malu, terhina, tertekan, bahkan menutup diri dari lingkungan sosialnya.

Korban verbal bullying yang memiliki kesiapan mental yang kuat dan stabilitas emosional yang matang cenderung lebih berani dalam menghadapi tantangan dan cobaan hidup. Pengalaman akibat direndahkan oleh sekelompok orang, membuat korban verbal bullying tidak takut untuk membuktikan diri lebih baik dari para pelaku bullying itu sendiri. Tidak jarang ditemukan bahwa mereka yang pernah menjadi korban verbal bullying memiliki kalimat-kalimat ampuh untuk menumbuhkan kembali kepercayaan diri yang hilang dan menjadi motivator bagi 
generasi di zamannya untuk mencegah perilaku verbal bullying menyerang orang-orang yang ada dilingkungannya.

\subsection{Dampak Negatif Verbal Bullying dalam Media Sosial}

Dari sekian dampak positif adanya verbal bullying, ternyata dampak negatifnya lebih mengkhawatirkan. Netizen maupun masyarakat seolah digiring untuk sepakat bahwa bullying ini menjadi kebiasaan atau adat yang berlaku di Indonesia. Mem-bully seseorang atau fenomena dianggap sebagai sesuatu yang wajar dan biasa untuk dijadikan bahan humor. Netizen maupun masyarakat dunia nyata tidak menyadari di balik ribuan orang yang tertawa atas apa yang terjadi pada seseorang baik karena kekurangan fisiknya maupun kesalahan yang dilakukannya.Para korban ini menyimpan kekecewaan yang mendalam di hatinya yang bisa mereka ungkapkan kembali dengan menjadi pelaku verbal bullying bahkan melakukan tindakan-tindakan yang dapat membahayakan nyawa para korban ini. Dampak negatif dari verbal bullying terhadap korbannya sangat signifikan. Berdasarkan pantauan peneliti dari pemilik akun yang pernah menjadi korban bullying secara verbal nampak adanya perubahan. Peneliti juga melengkapi data dengan metode wawancara dan menyebarkan kuesioner terbuka terhadap para korban verbal bullying yang mengemuka di media sosial. Berikut ini dipaparkan beberapa dampak negatif terkait verbal bullying yang mengemuka di media sosial, baik dalam status, posting-an, maupun komentar.

Kasus-kasus perilaku verbal bullying yang terjadi di lingkungan sosial, terutama di media sosial, cukup mengkhawatirkan. Verbal bullying merupakan masalah yang cukup krusial dalam pergaulan dewasa ini. Walaupun terlihat sepele, tetetapi masalah ini ternyata membawa dampak yang cukup serius bagi perkembangan jiwa dan emosional seseorang di masa depan. Korban verbal bullying yang sempat dikecam di media sosial bisa menyebabkan seseorang kehilangan harga diri. Korban verbal bullying ini mendapatkan rasa malu yang luar biasa terkait kalimat atau kata-kata yang diunggah di akun sosialnya ataupun mengomentari status orang lain di media sosial yang mengakibatkan banyak netizen menghujat seseorang.

Verbal bullying berpengaruh terhadap kemampuan seseorang menjalin hubungan dengan orang lain. Korban verbal bullying lebih sulit menjalin hubungan dengan orang lain dan lebih tidak puas dengan kehidupan korban verbal bullying. Hasil ini menekankan bahwa verbal bullying merupakan hal serius. Bullying bukanlah salah satu fase pertumbuhan yang harus dilewati oleh seorang. Akibat lebih fatal dari verbal bullying ini adalah adanya disfungsi sosial atau tidak berterimanya seseorang dalam kondisi lingkungan sosial tertentu.

Sikap tertutup, tidak asertif, cemas, dan rendah diri akan menurunkan prestasi belajar, menjadi hambatan dalam bergaul, dan menghambat perkembangan psikis para siswa yang menjadi korban bullying. Individu yang memiliki perasaan rendah diri, cemas, dan mudah terpengaruh dikatakan memiliki konsep diri yang negatif. Konsep diri dapat memengaruhi perkembangan perilaku asertif individu. Individu dengan konsep diri negatif memiliki kecemasan ketika mengungkapkan apa yang dirasakan sehingga akan menghambat individu tersebut untuk berperilaku asertif kepada orang lain. Individu dengan konsep diri negatif akan merasa dirinya tidak berharga dan tidak diterima oleh lingkungan, sehingga cenderung tidak 
berani mengambil risiko.

Korban bullying cenderung mengalami berbagai gangguan psikologis dan memiliki konsep diri negatif sehingga tidak dapat berperilaku asertif. Beberapa data berikut memuat adanya dampak negatif berupa disfungsi sosial.

Status di twitter dan path akun Florence

Jogja miskin, tolol, dan tak berbudaya. Teman-teman Jakarta-Bandung jangan mau tinggal Jogja.

Orang Jogja $B^{* * * * * * . ~ K a k a k ~ m a u ~ b e l i ~ P e r t a m a x ~} 95$ mentang-mentang pake motor harus antri di jalur mobil terus enggak dilayani. Malah disuruh antri di jalur motor yang stuck panjangnya gak ketulungan. Diskriminasi. Emangnya aku gak bisa bayar apa. Huh. KZL.

\section{Komentar}

“@florencje_Status S2, cara berpikir \& ngomongnya kok KAMPUNGAN. Keluar aja dari Yogya,"demikian komentardariakun@mercurianearth.

"Banyak yg mencintai jogja kan ya, makanya satu org yg ngatain jogja, semua pada maju. Oo dasar florence, kuliah si S2 UGM eh tetapi mulutnya," tulisUlvah,@ulpainaya.

Komentarlainnyadikirimkanakun@senorita_eve"kasihandgncewe@florencje_niy,ngakuny S2 tetapi cara bicarany enggak ada cerminan intelektualnya.

(konteks: status Florence muncul di media sosial akibat rasa tidak puas sang pemilik akun terhadap pelayan SPBU di Yogyakarta. Si pemilik akun merasa kesal karena harus mengatri panjang untuk membeli premium. Status itu dibuat dengan maksud menyinggung pegawai SPBU yang tidak melayani dengan prima).

Kicauan Florence di media sosial yang dinilai menghina warga Yogyakarta, berbuntut panjang. Setelah berbagai kecaman muncul di dunia maya, Florence sang pemilik akun juga harus berhadapan dengan pihak berwajib. Kalimat yang dilontarkannya di status yang bermaksud menyindir pelayanan SPBU Kota Yogyakarta membuatnya di-bully di media sosial. Perempuan yang disebut-sebut kuliah S-2 FH UGM ini resmi dilaporkan ke Polda DIY. Mem-bullyKota Yogyakarta dengan segala kekurangannya menurut Florence berbuntut balik ia yang menjadi korban bullying yang menyudutkan Florence sebagai seorang yang tidak berpendidikan. Diberitakan sebelumnya, akun media sosial kembali diramaikan dengan posting-an kontroversial dari pemilik akun path bernama Florence. Wajar saja, ia menuliskan keluh kesahnya saat mengantre BBM yang ternyata dinilai sangat menghina warga Yogyakarta. 
Hasil capture posting-an path tersebut kemudian diunggah ke jejaring twitter. Sontak saja, hal ini kemudian memancing protes keras dari para pengguna twitter lainnya. Bahkan komentarkomentar negatif pun melekat pada diri Florence.

\section{SIMPULAN}

Berdasarkan hasil penelitian dan pembahasan yang disajikan pada bab IV, penelitian ini dapat disimpulkan menjadi beberapa poin. Butir-butir simpulan yang dimaksud disajikan dalam paparan berikut ini.

Bentuk prilaku verbalbullying yang mengemuka di media sosial dinyatakan dengan bentuk yang beragam dengan maksud yang beragam pula. Pada penelitian ini peneliti memaparkan verbalbullying yang mengemuka di media sosial yang bermaksud melucu atau menghadirkan kesan humor kepada khalayak dunia maya. Kasus ini menyedot banyak komentar terhadap gambar dan kalimat-kalimat yang tertera untuk mendeskripsikannya. Sang pemilik akun awalnya hanya iseng dan ingin menghadirkan sensasi humor. Namun, di sisi lain banyak komentar yang malah menuduhnya melecehkan suatu peristiwa atau seseorang. Yang kedua, yaitu verbalbullying dalam media sosial yang bermaksud menyindir. Kalimat-kalimat bullying dengan maksud menghina ini banyak mengemuka di media sosial dan menimbulkan komentar-komentar netizen sehingga banyak hal negatif yang mewarnai media sosial tersebut. Ketiga, verbalbullying yang bermaksud menasihati. Kalimat menasihati ini tidak semua sesuai dengan maksud ketika dilontarkan di media sosial. Banyak netizen yang akhirnya mem-bullyposting-an-posting-an yang bermaksud menasihati. Keempat, verbalbullying yang bermaksud menyindir banyak mengemuka di media sosial. Bentuk ini ditujukan untuk menyindir tokoh, seseorang atau suatu tempat secara tidak langsung. Kelima, verbalbullying yang bermaksud mengancam. Kalimat-kalimat negatif yang memuat verbalbullying mengancam ini ditujukan seseorang atau netizen untuk memberikan efek jera terhadap seseorang atau pelaku tindakan verbalbullying yang disampaikannya lewat media sosial.

Bentuk penyimpangan verbalbullying ditinjau dari prinsip kesantunan berbahasa. Seperti yang telah dijabarkan dalam teori, prinsip kerja kesantunan berbahasa memuat enam maksim, yaitu maksim penghargaan, maksim kecocokan, maksim kesimpatian, maksim kebijaksanaan, maksim penerimaan, dan maksim kerendahhatian. Dalam analisis kasus verbalbullying yang mengemuka di media sosial hanya empat maskim yang muncul, yaitu penyimpangan terhadap maksim kebijaksanaan, kesimpatian, pemufakatan (kecocokan), dan penghargaan.

Dampak verbalbullying yang mengemuka di media sosial memiliki 2 pengaruh secara umum, yaitu pengaruh positif dan negatif. Dari kesekian pengaruh tersebut, dalam penelitian ini dipaparkan bahwa dampak negatifnya lebih banyak dan lebih mengkhawatirkan, terlebih jika korban verbalbullying tersebut tergolong masih remaja, bahkan anak-anak. Verbalbullying yang mengemuka di media sosial berpengaruh terhadap psikologi korban bullying, mendapat ancaman, merendahkan harga diri, membuat rasa tidak nyaman, selalu mencurigai setiap orang yang berkomentar, dipenjara, intimidasi lingkungan sosial, dan paling parah membuat korban bullying ini menjadi pelaku bullying dan membiasakan verbalbullying sebagai sebuah kewajaran atau wadah lelucon. 


\section{DAFTAR PUSTAKA}

Asrori, Imam. 2005. "Tindak Tutur dan Operasi Prinsip Sopan Santun dalam Wacana Rubrik Konsultasi Jawa Pos (Warkonjapos)”. Malang: Jurnal Bahasa dan Seni.

Ayu Suciartini, Ni Nyoman. 2012. Skripsi: Kesantunan Tuturan Guru dan Dampak Psikologisnya terhadap Siswa di SMA PGRI 1 Amlapura. Singaraja: Undiksha.

Chaer, Abdul. 2010. Kesantunan Berbahasa. Jakarta: Rhineka Cipta.

Dardjowidjojo, Soenjono. 2003. Psikolinguistik: Pengantar Pemahaman Bahasa Manusia. Jakarta: Yayasan Obor Indonesia.

Endardi, Joni. dkk. 2005. "Sopan Santun Bahasa Jawa di Lingkungan Keluarga; Sebuah Kajian Sosiodialektiologi.” Jurnal ilmiah. Yogyakarta: Humanika UGM.

F.J. Monks, A.M.P. Knoers, Siti Rahayu H. 2002. Psikologi perkembangan : pengantar dalam berbagai bagiannya. Yogyakarta : Gajah Mada University Press.

Harras. 2007. "Santun Berkomunikasi.” http://www.madhyasta.com (diakses tanggal 16 Mei 2018).

Hertinjung, Sri. 2013. Bentuk-bentuk Perilaku Bulllying di Sekolah Dasar. Artikel Seminar Parenting. Surakarta (hal.143).

Hertinjung, W.S, dkk. 2011. Profil kepribadian Pelaku dan Korban Bullying. Laporan Penelitian Kolaboratif. Surakarta: Universitas Muhammadiyah.

Jakarta Post. (2007). Bullying di Sekolah.http://www.thejakartapost.com. (diakses tanggal 13 Juli 2018).

Keraf, Gorys. 1997. Argumentasi dan Narasi. Jakarta: PT Gramedia Pustaka Utama.

Leech, Geoffrey. 1993. Prinsip-Prinsip Pragmatik. Terjemahan M.D.D.Oka. Jakarta: Universitas Indonesia. 
Louise, Cunmmings. 2007. Pragmatik: Sebuah Perspektif Multidisipliner. Terjemahan Eti Setiawati. Yogyakarta: Pustaka Belajar.

Margono, S. 2003. Metodologi Penelitian Pendidikan. Jakarta: PT Bhineka Cipta.

Megawangi, Ratna. 2010. Membangun Karakter Anak Melalui Brain-Based Parentik. Artikel ilmiah. Jakarta: Indonesia Heritage Foundation.

Moleong, Lexy. 1996. Metodologi Penelitian Kualitatif. Bandung: PT Remaja Rosdakarya.

Mulyani, Yeni. 2009. "Kesantunan Berbahasa dalam Mengungkapkan Perintah”. Artikel ilmiah. Yogyakarta: Humanika.

Naryanti, Amri. 2009. "Realisasi Kesantunan Berbahasa di kalangan Mahasiswa dalam Berinteraksi dengan Dosen dan Karyawan”. Skripsi (tidak diterbitkan). Malang: Universitas Negeri Malang.

Nurchaili. 2010. "Membentuk Karakter Siswa Melalui Keteladanan Guru.” Artikel ilmiah. Jurnal Pendidikan dan Kebudayaan. Humanika Yogyakarta.

Pranowo. 2009. Berbahasa Secara Santun. Yogyakarta: Pustaka Pelajar.

Pondok Bahasa. 2008. "Kesantunan Berbahasa Indonesia sebagai Pembentuk Kepribadian Bangsa”. Artikel Ilmiah. Bandung: Pondok Bahasa.

Purnamika, Lokita. 2010. "Pengaruh Usia dan Strategi Berbahasa; Sebuah Studi Pragmatik tentang Kesantunan Berbahasa pada Penutur Bahasa Indonesia”. Penelitian ilmiah (tidak diterbitkan). Singaraja: Universitas Pendidikan Ganesha.

Purwanti, Eko, dkk. 2006. "The Flouting of Politeness Maxims in Humor Discourse of Ektravagansa Comedy" Artikel ilmiah. Yogyakarta: Humanika UGM.

Ratna, Djuwita. (2007). Bullying: Kekerasan Terselubung di Sekolah. http://www.anakku.net. (Diakses tanggal 1 Agustus 2018).

Yayasan Semai Jiwa Amini. 2008. Bullying di tingkat Sekolah Dasar. Jakarta: Yayasan Semai Jiwa Amini. 